DOI: $10.2478 / \mathrm{sjdv}-2020-0001$

\title{
Evaluation of Efficacy and Safety Profile of Intense Pulsed Light Treatment in Melasma in Darker Skin Type
}

\author{
Nishant CHOUDHARY, Abhishek DE, Amrita SIL, Gobinda CHATTERJEE \\ ${ }^{1}$ Department of Dermatology, L.N. Medical College \& JK Hospital, Bhopal, India \\ ${ }^{2}$ Department of Dermatology, Calcutta National Medical College and Hospital, Kolkata, India \\ ${ }^{3}$ Department of Pharmacology, Institute of Post Graduation Medical Education and Research, Kolkata, India \\ Correspondence: Nishant Choudhary, E-mail: drnic.89@outlook.com \\ UDC 616.59-085.831-036.8
}

\begin{abstract}
Introduction. We undertook a prospective, interventional study to evaluate the efficacy and safety profile of Intense Pulsed light (IPL) treatment of melasma in dark skin phenotypes. Material and Methods. The study was conducted in 32 patients of skin type IV and V. IPL with $640 \mathrm{~nm}$ and $690 \mathrm{~nm}$ filters was used. The patients were called once a month to undergo 6 sessions. Melasma area and severity index (MASI) and Clinician Global Impression Scores were used for evaluation. We followed "per protocol" analysis. Results. Out of 26 patients who completed the treatment, 12 patients showed improvement, MASI remained unchanged in 10 patients and 4 patients showed deterioration. MASI scores before and after treatment were $6.70 \pm 3.53$ and $6.32 \pm 3.90$ ( $p$ value=0.6891). Erythema and pain were the common side effects noted. Seventeen out of 32 patients had thyroid disorders. Conclusion. IPL should be avoided as a first line therapy in darker skin type. However, it can be used as an adjuvant therapy in some cases after careful deliberations.
\end{abstract}

Key words: Intense Pulsed Light Therapy; Melanosis; Skin Pigmentation; Hyperpigmentation; Thyroid Diseases; Erythema; Pain; Treatment Outcome

\section{Introduction}

Melasma is one of the most common pigmentary disorders seen by dermatologists and often occurs among women with darker complexion (Fitzpatrick skin type IV-VI) (1). It is an acquired pigmentary disorder characterized by symmetrically distributed hyperpigmented macules, which can be confluent or punctate, mostly on the face. Exact pathogenesis is unknown and various factors have been proposed such as sun exposure (2), hormonal factors (3), stress, pollution (4) and drugs.

Treatment of melasma has always been a challenge often resulting in a non response, adverse events and temporary or partial remission. Lasers, including Q switched Nd:YAG, are slowly becoming popular in the treatment of melasma; however, their efficacy and safety remains controversial $(5,6)$. Some recent studies have suggested that intense pulse light (IPL) may be effective for melasma $(7,8)$. However, similar studies in darker skin type are very scarce. We have done a prospective, interven- tional study to evaluate efficacy and safety profile of IPL in melasma in darker skin types.

\section{Material and Methods}

The study was conducted at a tertiary care institution after having been granted the permission by the institutional ethical committee. Thirty-two consecutive patients having melasma, who fulfilled the inclusion and exclusion criteria, were included in the study. All patients aged 18 years and above, attending dermatology outpatient department, who were diagnosed with melasma and gave their consent were included in the study. The patients were subjected to IPL treatment after the proper evaluation. Written informed consent was taken from every patient after explaining the treatment procedure and likely repercussions in their vernacular language.

Patients with connective tissue disorders, psoriasis, vitiligo and keloidal tendencies were excluded from the study. Pregnant and 
lactating patients were also excluded from the study. Institutional ethical clearance was taken in compliance with the Declaration of Helsinki. IPL with $640 \mathrm{~nm}$ \& $690 \mathrm{~nm}$ cut off filters were used. The patients were called once a month to undergo 6 sessions.

Details of the results and side effects were noted in case record forms. Melasma area and severity index (MASI) scores were noted in every visit. Association of melasma with thyroid disorders was also investigated. The patients were evaluated for thyroid disorders by measuring T3, T4, TSH levels and also by gathering information regarding intake of thyroid supplement for the same disorders.

If $50-100 \%$ reduction in MASI Scire was noted, the results were evaluated as good; if MASI reduction was less than $50 \%$ results were evaluated as mild, and as poor if there was no redustion of MASI or increase in MASI. Parameters of IPL treatment are presented in Table 1.

\section{Statistical Analysis}

We followed "per protocol" analysis, whereby only those patients who completed the entire study period (baseline and 5 follow up session) were considered for the final analysis. Melasma area and severity index (MASI) was calculated by considering 4 areas of face-forehead $(30 \%)$, right malar $(30 \%)$, left malar $(30 \%)$ and chin (10\%). Other than this area $(A)$, two other factors were considered - darkness (D) and homogeneity (H). MASI was calculated by $(D+H) \times A$.

Total MASI score:
Forehead $0.3(\mathrm{D}+\mathrm{H}) \mathrm{A}+$ right malar $0.3(\mathrm{D}+\mathrm{H})$ $A+$ left malar $0.3(D+H) A+$ chin $0.1(D+H) A$. For the statistical analysis, $p$ value was calculated using Mann Whitney $U$ test $p$ value of $<0.05$ was taken as statistically significant.

\section{Results}

Of 32 study patients, 25 were female and 7 were male. We followed "per protocol" analysis, whereby only those patients who completed the entire study (6 sessions) were evaluated for the effect of IPL. The age of our patients ranged from 24-56 years, the mean age being $37.9 \pm 7.9$ years. Young adults in the 20 40 age were most commonly affected (65.6\%). All patients belonged to Fitzpatrick skin type IV and V, the phototype IV being the most common, $n=19$ patients. The presence of thyroid disorders was also evaluated. Out of 32 patients, 17 (53.12\%) had thyroid disorder: 16 cases of hypothyroidism and 1 case of hyperthyroidism. Out of these 16 patients, 7 were newly diagnosed, and the others were already on treatment. Of these 17 patients, 2 also had concomitant diabetes. As for the relation between MASI value and the presence of thyroid disorders, there was a mild correlation seen in Spearman's rho (0.119); however, the $p$ value was found to be 0.56 .

A positive family history of melasma was present in 16 (50\%) patients. Based on clinical patterns, we found malar type being predominant as it was seen in $21(62.13 \%)$ patients and most i.e. $30(93.75 \%)$ of them had patchy morphology. On the basis of Wood's lamp

Table 1. IPL parameters

\begin{tabular}{ccccc} 
Number of Patients & Filters used & Number of treatments & Interval & Dose \\
26 & 6 & 4 weeks & Fluence: \\
& $640 \mathrm{~nm}$, & & $20-30 \mathrm{~J} / \mathrm{cm}^{2}$ \\
$690 \mathrm{~nm}$ & & & (triple pulse) \\
& & & Pulse: $4-6 \mathrm{~ms}$ \\
& & Delay: $20-30 \mathrm{~ms}$ \\
\hline
\end{tabular}

Table 2. Results of the IPL treatment 

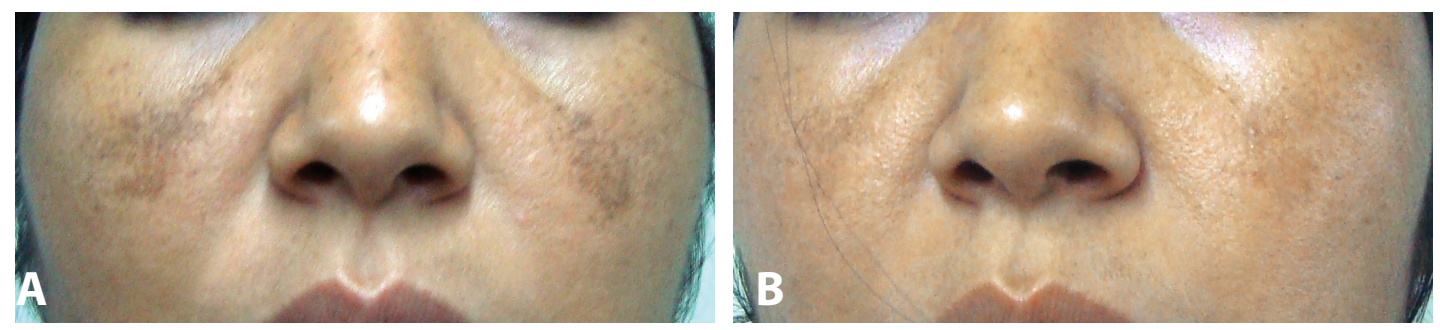

Figures 1 A and B. (A) At beginning of treatment (B) Improvement after 6 sessions

Table 3. Improvement in MASI scores in patients who completed the study $(n=26)$

\begin{tabular}{lccc} 
& $\begin{array}{c}\text { MASI score (baseline) } \\
(\mathrm{n}=26)\end{array}$ & $\begin{array}{c}\text { MASI score (end of treatment) } \\
(\mathrm{n}=26)\end{array}$ & $\begin{array}{c}\text { P value } \\
\text { (in between groups) }\end{array}$ \\
Mean \pm SD & $6.70 \pm 3.53$ & $6.32 \pm 3.90$ & 0.681 \\
Median (IQR) & $5.70(4.8,7.2)$ & $5.7(3.6,7.2)$ & \\
Range & $2.40-15.60$ & $1.8-19.8$ & \\
\hline
\end{tabular}

$\mathrm{SD}=$ Standard deviation, IQR = Interquartile range, $\mathrm{P}$ value between groups by Mann Whitney $\mathrm{U}$ test

examination, epidermal type was the predominant type observed in 17 patients, the mixed one was observed in 13 patients and dermal type was found in 1.

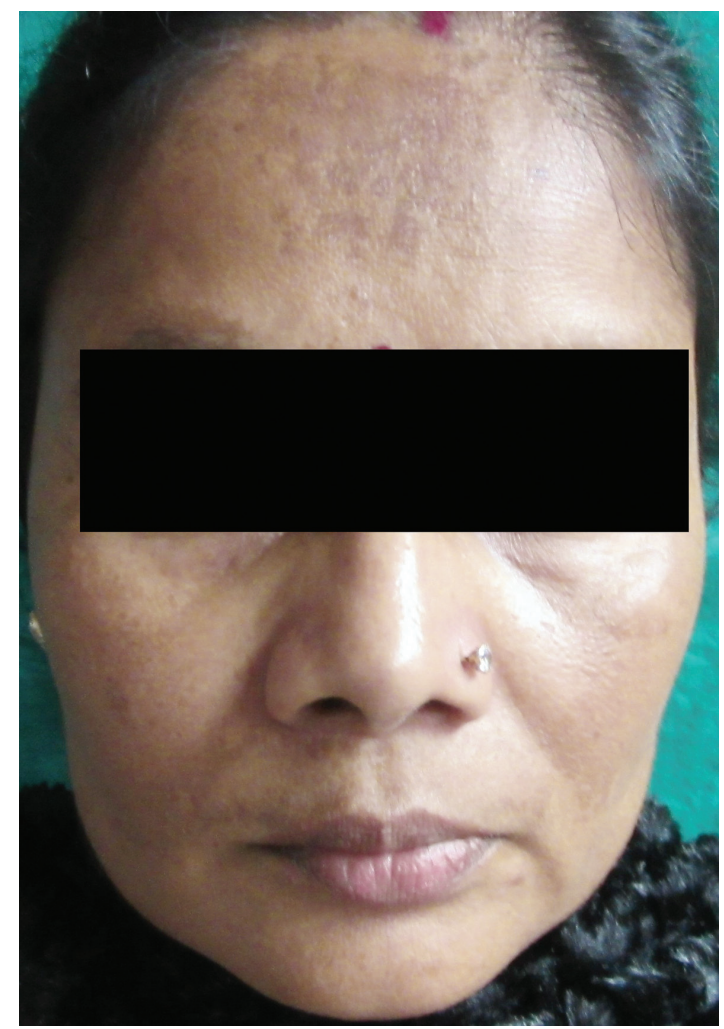

Figures 2 A and B. (A) At beginning of treatment (B) Increase in MASI following treatment
Of the 32 patients treated, six patients discontinued treatment due to the development of significant post inflammatory hyperpigmentation $(\mathrm{PIH})$ and were kept out of analysis. Of the 26 patients who completed the

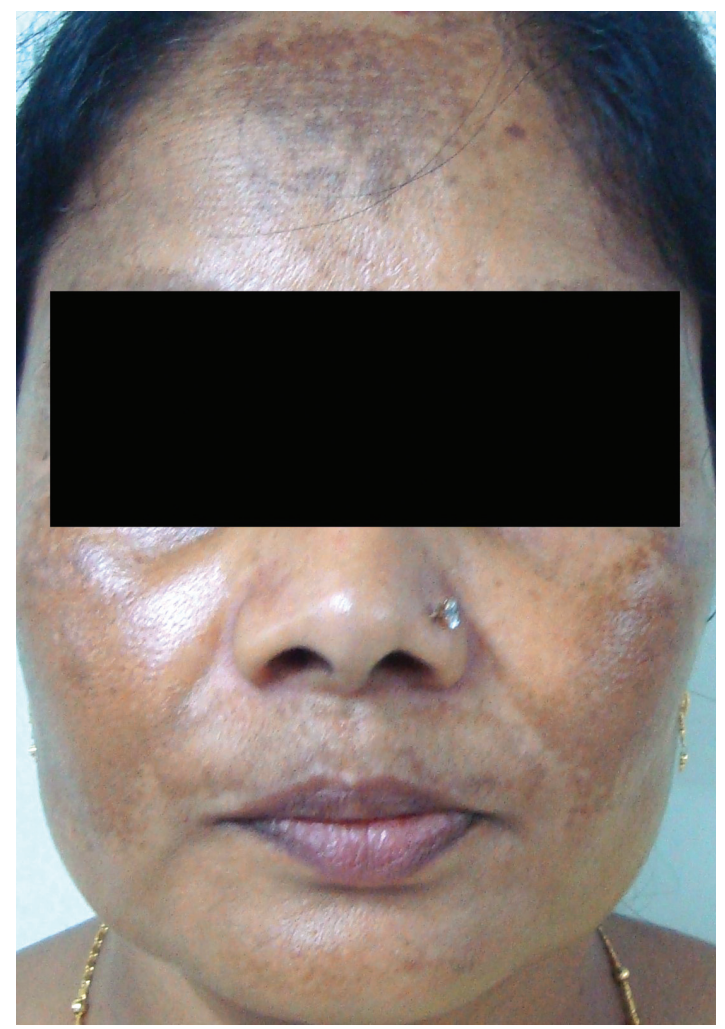




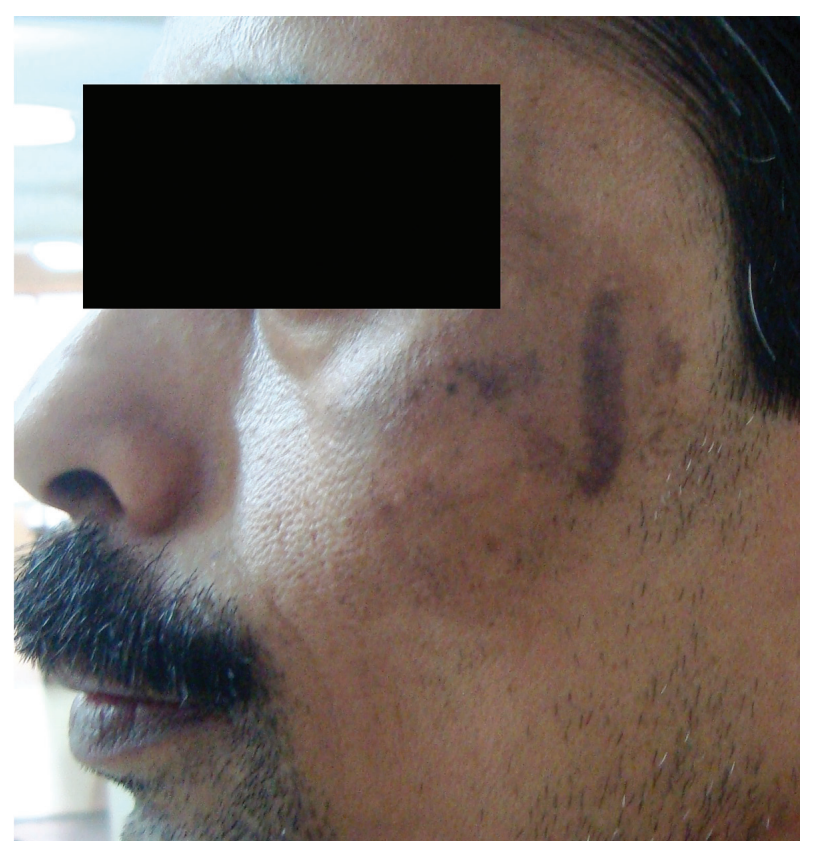

Figure 3. Post inflammatory hyperpigmentation

treatment, 12 patients showed improvement in MASI, (Figure 1) whereas MASI remained unchanged in 10 patients and 4 patients showed deterioration (Figure 2, Table 2). The mean MASI score of all the 26 patients taken together before the start of treatment was $6.7 \pm 3.53$ and after the treatment was 6.32 \pm 3.90 . However, the improvement was found to be statistically insignificant ( $p$ val$\mathrm{ue}=0.681$ ) in Mann Whitney tet (Table 3).

When only the patients who had shown improvement were taken, mean MASI of those 12 patients, before and after the treatment was $6.41 \pm 3.53$ and $4.85 \pm 3.90$, respectively.

Mild pain, burning sensation and erythema were common side effects noted. No permanent side effects were seen. Treatment was discontinued in 6 patients following post inflammatory hyperpigmentation (PIH) (Figure 3).

We tried to find the predictability of the response against the clinical variable. The response was found to be insignificant for both the clinical types, the malar type $(p=0.681)$ and the craniofacial type $(p=0.643)$; however, the malar type showed to be correlating better with MASI improvement than the craniofacial type (Spearman's rho value showing moderately strong correlation $\rho=-0.245$ ) (Table 3). There was no correlation found between clinical response and baseline MSI score, familiy history and presence of thyroid disorder $(p>0.05)$.

\section{Discussion}

Melasma is one of the most common pigmentary disorders and often occurs in persons with darker complexion. It causes significant cosmetic disfigurement which leads to psychological stress as well. There are various modalities of treatment in the form of topical creams and ointments (steroid and hydroquinone containing triple combination cream $(9,10)$, arbutin (11), kojic acid (12), hydroquinone), oral agents (tranexamic acid) $(13,14)$ and cosmetic procedures such as chemical peeling (glycolic acid (15), trichloroacetic acid (16) etc.). However, treatments available are found to be either ineffective or partially effective. Many of these treatments have side effects when used for long term.

The invention of lasers and IPL offers a new scope in the treatment of this recalcitrant condition. Various lasers have been tried for treatment of melasma such as QS Nd:YAG $(5,1)$, Erbium YAG (8), QS Ruby (6) and Fractional laser (19). In a Brazilian study involving 302 patients, a high prevalence was found in adult females with skin types III-IV (20). Of the 302 patients, skin type III (34.8\%) and skin type IV (384\%) were prevailing. In our study 32 patients were recruited and they belonged to Fitzpatrick skin types IV and V. Most of the patients belonged to type IV (59.37\%).

In the study conducted by Lutfi et al. in patients with melasma, the frequency of thyroid disorders $(58.3 \%)$ was 4 times greater than in the control group (21). Estrogen, progesterone, or both could be the triggering factor in the development of melasma in women who have a particular predisposition toward both melasma and thyroid autoimmunity. In our study, thyroid disorders were present in $53.12 \%$ of patients. Also a mild correlation was noted between MASI score and the presence of thyroid abnormalities, the correlation coefficient (Spearman's rho) being 0.119.

Wang et al. conducted a study on treatment of melasma using IPL involving 17 patients. The patients underwent four sessions at 4-week intervals (8). The patients were also given $4 \%$ hydroquinone cream and broad-spectrum sunscreens. Sixteen patients in the control group were treated with hydroquinone cream and sunscreens. The treatment efficacy was evaluated using reflectance spectrophotometer and patients' satisfaction questionnaire. The patients in the IPL group achieved an average 
of $39.8 \%$ improvement in relative melanin index, compared to $11.6 \%$ improvement in the control group $(p<0.05)$ at week 16 . More than $50 \%$ clearance of lesion was observed in 35\%, 26$50 \%$ clearance in $35 \%$ and $<25 \%$ clearance in $30 \%$ of patients. Two patients in the intense pulsed light group, however, experienced transient post-inflammatory hyperpigmentation.

A study was conducted by Zoccali et al. in 38 patients to see result of IPL in treatment of melasma (22). In this study $80-100 \%$ improvement in lesion was seen in $47.37 \%$ (18 patients), $60-79 \%$ improvement in $28.95 \%$ (11 cases) and moderate improvement $(40-59 \%)$ in $13.16 \%$ of patients ( 5 cases) and poor in 4 cases $(10.52 \%)$. They have concluded that IPL stands out as an effective tool in the treatment of melasma, with a very low risk of complications and an excellent satisfaction rate among patients.

In a study conducted by Moreno et al to evaluate the efficacy of IPL in treatment of melasma better results were obtained for epidermal (76-100\% clearance) than mixed melasma which showed $<25 \%$ clearance of lesion (7). Superficial and deep melanocytic lesions were treated by an intense pulsed light source with thefollowing parameters: filters of 590,615 , and $755 \mathrm{~nm}$, fluence energy of 34-38 $\mathrm{J} / \mathrm{cm}^{2}$, double mode, a pulse width of 3.8-4.5 $\mathrm{msec}$, and a delay of $20 \mathrm{msec}$, at 4 to 8 week intervals. Two treatment sessions were applied to superficial lesions, while deep ones received four sessions. Side effects were minimal, with no permanent side effects seen.

Our study results were in contrast to those mentioned above. $50-100 \%$ improvement was noted in 1 patient, $<50 \%$ reduction in 11 patients; whereas the remaining 14 showed no improvement or increase in MASI. The inferior response in our patients can be explained by the facts that we have done the study on darker skin types only. In addition we did not use hydroquinone or any other bleaching agent in our patients.

Darker skin types are also more prone to side effects. PIH developed in 6 of our patients; therefore, the treatment was discontinued in those patients. Of these 6 patients, 4 were of Fitzpatrick type $\mathrm{V}$ skin and 2 of Fitzpatrick type IV. Thus darker skin appears to be more at risk of developing $\mathrm{PIH}$.

However, in some of our patients $(n=12)$ IPL seems to be working well even without any other bleaching agent; but we did not find any strong correlation between the response pattern and most of the clinical variables In our study, better response was noted in patients with malar type of melasma and in patients with low MASI score.

\section{Conclusion}

We suggest that IPL should be avoided as the first line therapy in treatment of melasma especially in darker skin type. However, it can be used as an adjuvant treatment in some patients. We have also concluded that in case of darker skin types, IPL should be used with caution in the treatment of melasma as there is a high chance of post inflammatory hyperpigmentation. We also found that there was association between melasma and hypothyroidism and many of these patients may be unmasked only when investigated for the same.

\section{Abbreviations}

IPL - intense pulse light

MASI - Melasma area and severity index

$\mathrm{PIH}$ - Post inflammatory hyperpigmentation

\section{References}

1. Pasricha JS, Khaitan BK, Dash S. Pigmentary disorders in India. Dermatol Clin. 2007;25(3):343-52.

2. Ortonne JP, Arellano I, Berneburg M, Cestari T, Chan $\mathrm{H}$, Grimes P, et al. A global survey of the role of ultraviolet radiation and hormonal influences in the development of melasma. J Eur Acad Dermatol Venereol. 2009;23(11):1254-62.

3. Jang YH, Lee JY, Kang HY, Lee ES, Kim YC. Oestrogen and progesterone receptor expression in melasma: an immunohistochemical analysis. J Eur Acad Dermatol Venereol. 2010;24(11):1312-6.

4. Roberts WE. Pollution as a risk factor for the development of melasma and other skin disorders of facial hyperpigmentation - is there a case to be made? J Drugs Dermatol. 2015;14(4):337-41.

5. Lee DB, Suh HS, Choi YS. A comparative study of lowfluence 1,064 nm Q-Switched Nd: YAG laser with or without chemical peeling using Jessner's solution in melasma patients. J Cosmet Laser Ther. 2014;16(6):264-70.

6. Taylor CR, Anderson RR. Ineffective treatment of refractory melasma and postinflammatory hyperpigmentation by Q $\square$ switched ruby laser. J Dermatol Surg Oncol. 1994;20(9):592-7.

7. Moreno Arias GA, Ferrando J. Intense pulsed light for melanocytic lesions. Dermatol Surg. 2001;27(4):397400. 
8. Wang CC, Hui CY, Sue YM, Wong WR, Hong HS. Intense pulsed light for the treatment of refractory melasma in Asian persons. Dermatol Surg. 2004;30(9):1196-200.

9. Jutley GS, Rajaratnam R, Halpern J, Salim A, Emmett C. Systematic review of randomized controlled trials on interventions for melasma: an abridged Cochrane review. J Am Acad Dermatol. 2014;70(2):369-73.

10. Chan R, Park KC, Lee MH, Lee ES, Chang SE, Leow $\mathrm{YH}$, et al. A randomized controlled trial of the efficacy and safety of a fixed triple combination (fluocinolone acetonide $0.01 \%$, hydroquinone $4 \%$, tretinoin $0.05 \%$ ) compared with hydroquinone $4 \%$ cream in Asian patients with moderate to severe melasma. Br J Dermatol. 2008;159(3):697-703.

11. Maeda K, Fukuda M. Arbutin: mechanism of its depigmenting action in human melanocyte culture. J Pharmacol Exp Ther. 1996;276(2):765-9.

12. Monteiro RC, Kishore BN, Bhat RM, Sukumar D, Martis J, Ganesh HK. A comparative study of the efficacy of $4 \%$ hydroquinone vs $0.75 \%$ Kojic acid cream in the treatment of facial melasma. Indian J Dermatol. 2013;58(2):157.

13. Wu S, Shi H, Wu H, Yan S, Guo J, Sun Y, et al. Treatment of melasma with oral administration of tranexamic acid. Aesthetic Plast Surg. 2012;36(4):964-70.

14. Karn D, Kc S, Amatya A, Razouria EA, Timalsina M. Oral tranexamic acid for the treatment of melasma. Kathmandu Univ Med J (KUMJ). 2012;10(4):40-3.
15. Grover C, Reddu BS. The therapeutic value of glycolic acid peels in dermatology. Indian $\mathrm{J}$ Dermatol Venereol Leprol. 2003;69(2):148-50.

16. Kumari R, Thappa DM. Comparative study of trichloroacetic acid versus glycolic acid chemical peels in the treatment of melasma. Indian J Dermatol Venereol Leprol. 2010;76(4):447.

17. Wattanakrai $P$, Mornchan R, Eimpunth S. Low $\square$ fluence $\mathrm{Q} \square$ switched neodymium $\square$ doped yttrium aluminum garnet $(1,064 \mathrm{~nm})$ laser for the treatment of facial melasma in Asians. Dermatol Surg. 2010;36(1):76-87.

18. Manaloto RM, Alster T. Erbium: YAG laser resurfacing for refractory melasma. Dermatol Surg. 1999;25(2):121-3.

19. Lee HS, Won CH, Lee DH, An JS, Chang HW, Lee JH, et al. Treatment of melasma in Asian skin using a fractional $1,550 \square \mathrm{nm}$ laser: an open clinical study. Dermatol Surg. 2009;35(10):1499-504.

20. Tamega Ade A, Miot LD, Bonfietti C, Gige TC, Marques ME, Miot HA. Clinical patterns and epidemiological characteristics of facial melasma in Brazilian women. J Eur Acad Dermatol Venereol. 2013;27(2):151-6.

21. Lutfi RJ, Fridmanis M, Misiunas AL, Pafume O, Gonzalez EA, Villemur JA, et al. Association of melasma with thyroid autoimmunity and other thyroidal abnormalities and their relationship to the origin of the melasma. J Clin Endocrinol Metab. 1985;61(1):28-31.

22. Zoccali G, Piccolo D, Allegra P, Giuliani M. Melasma treated with intense pulsed light. Aesthetic Plast Surg. 2010;34(4):486-93.

\section{Evaluacija efikasnosti i bezbednosti tretmana melazme inten- zivnom pulsirajućom svetlošću na tamnijoj koži}

\section{Sažetak}

Uvod. Sproveli smo prospektivnu, interventnu studiju da bismo procenili efikasnost i bezbednost intenzivne pulsirajuće svetlosti (IPS) u lečenju melazme kod fototipa IV i V. Materijal i metode. Studija je izvedena na 32 pacijenta sa kožom tipa IV i V. Primenjena je intenzivna pulsirajuća svetlost sa filterima $640 \mathrm{~nm}$ i $690 \mathrm{~nm}$. Pacijenti su pozivani jednom mesečno na šest seansi. Za evaluaciju su korišćeni indeks površine i intenziteta melazme (Melasma area and severity index - MASI i ocena opšteg kliničkog utiska (Clinician Global Impression Scores). Rezultati. Od 26 pacijenata koji su završili tretman, kod 12 je došlo po poboljšanja, MASI je ostao nepromenjen kod 10 pacijenata, a do pogoršanja je došlo kod četiri pacijenta. MASI vrednosti pre i posle tretmana bile su 6,70 $\pm 3,53$ i 6,32 $\pm 3,90$ (p-vrednost $=0,6891$. Eritema i bol su primećeni kao česti prateći efekti. Od 32 pacijenta, 17 su imali tiroidni poremećaj. Zaključak. Intenzivnu pulsirajuću svetlost bi trebalo izbegavati kao terapiju prve linije kod tamnije kože. Međutim, može se koristiti kao pomoćna terapija u nekim slučajevima posle pažljivog razmatranja.

Ključne reči: Terapija intenzivnim pulsirajućim svetlom; Melazma; Pigmentacija kože; Hiperpigmentacija; Tiroidne bolesti; Eritem; Bol; Ishod terapije

Received 2.03.2020.

Accepted 4.06.2020. 